\title{
Effect of exogenous amylase on lactation performance of dairy cows fed a high-starch diet
}

\author{
Arturo S. R. Andreazzi, ${ }^{*}$ Marcos N. Pereira, $\$ \ddagger^{1}$ Ronaldo B. Reis, ${ }^{*}$ Renata A. N. Pereira, $₫ \S$ \\ Nilson N. Morais Júnior,† Tiago S. Acedo,\# Rafael G. Hermes,\# and Cristina S. Cortinhas\# \\ *School of Veterinary Medicine, Federal University of Minas Gerais, Belo Horizonte, MG 30161-970, Brazil \\ †Department of Animal Sciences, University of Lavras, Lavras, MG 37200-000, Brazil \\ łBetter Nature Research Center, ljaci, MG 37205-000, Brazil \\ §Minas Gerais Agricultural Research Enterprise (Epamig), Lavras, MG 37200-000, Brazil \\ \#DSM Produtos Nutricionais Brasil S.A., São Paulo, SP 01451-905, Brazil
}

\begin{abstract}
Exogenous amylase supplementation can increase starch and fiber digestibility in lactating dairy cows. We evaluated the effect of exogenous amylase supplementation on diets with high starch concentration $(32 \%$ of dry matter). Twenty-eight Holstein cows $(171 \pm 80 \mathrm{~d}$ in milk, 4 primiparous) received a standard diet for 14 $\mathrm{d}$ and then a treatment for $63 \mathrm{~d}$, in a covariate-adjusted randomized block design with repeated measures over time. Treatments were amylase $[0.5 \mathrm{~g}$ of Ronozyme RumiStar (DSM Nutritional Products, Basel, Switzerland) per $\mathrm{kg}$ of total mixed ration dry matter] or control. The diets contained (\% of dry matter): $39.4 \%$ corn silage, $11.2 \%$ rehydrated and ensiled mature corn grain, and $11.7 \%$ finely ground mature corn. Amylase increased milk yield (32.3 vs. $33.0 \mathrm{~kg} / \mathrm{d}$ ) and reduced dry matter intake (20.7 vs. $19.7 \mathrm{~kg} / \mathrm{d}$ ), increasing feed efficiency (1.52 vs. 1.63). Amylase also increased milk lactose synthesis (1.49 vs. $1.56 \mathrm{~kg} / \mathrm{d}$ ) and plasma glucose concentration (59.3 vs. $68.6 \mathrm{mg} / \mathrm{dL}$ ). Secretions of milk fat and protein did not differ. Although milk urea $\mathrm{N}$ did not differ, amylase reduced the concentration of urea $\mathrm{N}$ in blood, suggesting an increase in ruminal starch degradation. However, the total-tract apparent digestibility of starch (96.3\% of intake) and neutral detergent fiber ( $44.4 \%$ of intake), ruminal fermentation profile, and microbial yield estimated by urinary allantoin excretion did not differ. Cows fed amylase sorted in favor of long feed particles and against short particles, had shorter chewing activity (780 vs. 699 $\mathrm{min} / \mathrm{d}$ ), and had fewer meals per day (11.5 vs. 9.7). Amylase improved the feed efficiency of lactating cows
\end{abstract}

Received December 21, 2017.

Accepted March 28, 2018.

${ }^{1}$ Corresponding author: mpereira@dzo.ufla.br fed a high-starch diet; the enzyme increased milk yield and reduced intake.

Key words: feed efficiency, intake, sorting behavior, starch digestibility

\section{INTRODUCTION}

Dietary starch is important to maximize ruminal microbial yield (Hall and Herejk, 2001) and is a major contributor to the energy required for lactation by dairy cattle. The supplementation of lactating cows with exogenous amylase stable in rumen fluid (Klingerman et al., 2009) can increase ruminal starch digestibility (Nozière et al., 2014). Increased ruminal starch availability may increase ruminal microbial yield and feed efficiency by intake regulation induced by increased liver oxidation of propionate (Allen et al., 2009). However, increased ruminal starch digestion can undesirably induce ruminal acidosis, leading to reductions in ruminal microbial synthesis and milk solids secretion (Oba and Allen, 2003a).

The effect of nutritional strategies on ruminal starch digestibility seems to be dependent on the type of starch in the diet. Oba and Allen (2003b) observed that the increase in ruminal starch digestibility when high-moisture corn replaced finely ground mature corn in high (32\%) and low (21\%) starch diets was 24.2 and 12.6 percentage units, respectively, suggesting that the ruminal capacity to digest more resistant starch sources is limited. The accumulation of VFA after $6 \mathrm{~h}$ of ruminal in vitro fermentation was increased when amylase was added to flint corn but had no effect on floury corn (Klingerman et al., 2009). The total-tract digestibility of NDF has also been improved by exogenous amylase supplementation (Gencoglu et al., 2010; Weiss et al., 2011), supposedly by increased ruminal availability to fiber digesting bacteria of starch hydrolysis products (Cotta, 1988; Tricarico et al., 2008). 
Long-term effects of amylase supplementation on lactation performance, DMI, and feed efficiency of lactating cows have been inconsistent. The supplementation of a $21 \%$ starch diet with amylase for $10 \mathrm{wk}$ increased milk yield, had no effect on DMI, and tended to increase the milk to DMI ratio (Ferraretto et al., 2011). Gencoglu et al. (2010) observed a reduction in DMI, no effect on milk yield, and an increase in feed efficiency when a $21 \%$ starch diet was supplemented with amylase for $12 \mathrm{wk}$. Weiss et al. (2011) supplemented amylase to lactating cows fed a $26 \%$ starch diet containing coarsely ground corn for $14 \mathrm{wk}$ and did not detect changes in milk yield, DMI, and feed efficiency. The long-term effect of amylase supplementation to diets with a high starch concentration has not been evaluated. Highstarch diets may be an economic alternative when corn prices are low and may be more responsive to amylase supplementation than low-starch diets. The objective of this experiment was to evaluate the 9-wk supplementation of lactating cows fed a $32 \%$ starch diet from corn silage, finely ground corn, and rehydrated and ensiled corn grain with exogenous amylase. We hypothesized that adding exogenous amylase to the high-starch diet would increase the milk to DMI ratio and the digestibility of starch.

\section{MATERIALS AND METHODS}

The experiment was conducted from August 20 to November 4, 2012, in an open-walled, sand-bedded tiestall barn with fans and high-pressure sprinklers at the Better Nature Research Center (http://www .holandesflamma.com.br/) under a protocol approved by the University of Lavras Bioethics Committee in Utilization of Animals.

\section{Cows, Experimental Design, and Treatments}

Twenty-eight Holstein cows $(171 \pm 80$ DIM at the beginning of the experiment, 4 primiparous) were milked 3 times per day starting at 0500,1300 , and $2000 \mathrm{~h}$ in an herringbone parlor and the TMR for each treatment was mixed 2 times per day in a $1.2-\mathrm{m}^{3}$ stationary vertical mixer (Unimix 1200, Casale, São Carlos, Brazil). New feed was offered at 0600 and $1300 \mathrm{~h}$ in amounts to allow for 7 to $10 \%$ of the offered amount as daily refusal and was pushed up at least 10 times per d. Cows were individually fed the same TMR for a 14-d standardization period. On d 9 to 14 of this period, DMI, milk yield, and solids concentration, MUN, BW, and BCS were measured and used as covariate in the statistical model. Then, cows were paired blocked primarily by parity (1 vs. >1) and secondarily by milk yield and randomly assigned within blocks to a treatment for $63 \mathrm{~d}$ of a comparison period. Treatments were control or amylase. The exogenous amylase produced by Bacillus licheniformis (Ronozyme RumiStar, DSM Nutritional Products, Basel, Switzerland) was mixed with ground corn and added to the TMR ( $0.5 \mathrm{~g}$ of enzyme per $\mathrm{kg}$ of TMR DM) to achieve 300 Kilo Novo units of amylase activity $/ \mathrm{kg}$ of TMR DM. One Kilo Novo unit is the amount of enzyme that releases in a 2-step $\alpha$-amylase $/ \alpha$-glucosidase reaction, $6 \mu \mathrm{mol}$ of $p$-nitrophenol per min from $1.86 \mathrm{~m} M$ ethylidene- $\mathrm{G} 7-p$ nitrophenyl-maltoheptaoside at $\mathrm{pH} 7.0$ and $37^{\circ} \mathrm{C}$ (Jung and Vogel, 2008). The TMR mixer was completely unloaded after the mixing of each diet, and the control treatment was mixed before amylase. The dosage of enzyme was based on previous studies that demonstrated efficacy (Klingerman et al., 2009; Gencoglu et al., 2010).

\section{Data Collection and Laboratory Procedures}

Feed intake was calculated individually as the difference between feed offered and orts recorded daily. The DM concentration of the corn silage and of the rehydrated corn grain silage were monitored weekly with a Koster Moisture Tester (Koster Crop Tester Inc., Brunswick, $\mathrm{OH}$ ) and the TMR was adjusted accordingly. Rehydrated and ensiled corn is the product of homogeneous addition of water to ground mature kernels to obtain more than $30 \%$ moisture concentration for ensiling (Andrade Filho et al., 2010), capable of increasing ruminal starch fermentation by prolamin degradation (Ferraretto et al., 2015). Samples of feeds and orts per cow were obtained daily and frozen for the formation of weekly composites based on equal asfed amounts of daily samples. Composite samples were dried in forced-air oven at $55^{\circ} \mathrm{C}$ for $72 \mathrm{~h}$ and ground to pass a 1-mm mesh screen (Wiley mill, Thomas Scientific, Swedesboro, NJ). The DM concentration was determined by drying at $100^{\circ} \mathrm{C}$ for $24 \mathrm{~h}$. The CP concentration was determined with a micro Kjeldahl apparatus (method 984.13; AOAC International, 2012), ash by incineration at $550^{\circ} \mathrm{C}$ for $8 \mathrm{~h}$, the ash-free NDF by filtration in porous crucibles with heat-stable $\alpha$-amylase and sodium sulfite (Van Soest et al., 1991), and the ether extract as in AOAC International (2012; method 920.39). The NFC fraction was calculated: $100-(\mathrm{CP}$ + ether extract + ash + NDF). Starch was analyzed enzymatically according to Hall (2009). The nutrient composition of the consumed TMR was calculated as the total nutrient intake of the cows (offered minus refusals) divided by the total DMI of the treatment. The ingredient composition of the offered TMR was 
Table 1. Composition of the offered TMR in ingredients, of the consumed TMR in nutrients, and particle size distribution on control and amylase treatments (\% of DM unless otherwise indicated)

\begin{tabular}{|c|c|c|}
\hline Item & Control & Amylase \\
\hline Corn silage $^{1}$ & 39.4 & 39.4 \\
\hline Tifton hay $^{2}$ & 7.4 & 7.4 \\
\hline Rehydrated and ensiled corn & 11.2 & 11.2 \\
\hline Finely ground corn & 11.7 & 11.7 \\
\hline Soybean meal (53.6\% CP) & 16.8 & 16.8 \\
\hline Citrus pulp & 11.1 & 11.1 \\
\hline Urea & 0.4 & 0.4 \\
\hline Sodium bicarbonate & 0.6 & 0.6 \\
\hline Magnesium oxide & 0.3 & 0.3 \\
\hline Salt & 0.2 & 0.2 \\
\hline Limestone & 0.6 & 0.6 \\
\hline Marine algae meal & 0.2 & 0.2 \\
\hline Minerals and vitamins ${ }^{3}$ & 0.3 & 0.3 \\
\hline $\mathrm{CP}$ & 17.7 & 17.7 \\
\hline $\mathrm{NDF}$ & 35.5 & 35.4 \\
\hline Forage NDF & 22.4 & 22.4 \\
\hline Ether extract & 4.5 & 4.3 \\
\hline Ash & 6.1 & 6.2 \\
\hline $\mathrm{NFC}^{4}$ & 36.2 & 36.4 \\
\hline Starch & 32.0 & 32.2 \\
\hline Starch from corn silage & 12.2 & 12.2 \\
\hline Starch from rehydrated and ensiled corn & 8.62 & 8.63 \\
\hline Starch from ground corn & 9.76 & 9.76 \\
\hline DM, $\%$ of as fed & 51.3 & 51.3 \\
\hline Feed particles $>19 \mathrm{~mm},{ }^{5} \%$ of as fed & $6.7 \pm 1.8$ & $6.7 \pm 1.9$ \\
\hline Feed particles $8-19 \mathrm{~mm},{ }^{5} \%$ of as fed & $23.9 \pm 4.5$ & $23.7 \pm 4.0$ \\
\hline Feed particles $<8 \mathrm{~mm},{ }^{5} \%$ of as fed & $69.4 \pm 4.3$ & $69.6 \pm 4.3$ \\
\hline
\end{tabular}

1\% of DM: CP 8.8\%; NDF 46.1\%; ether extract 5.9\%; ash 3.2\%; starch $31.0 \%$; DM $31.0 \%$ of as fed.

${ }^{2} \%$ of DM: $\mathrm{CP} 12.1 \%$; NDF $63.0 \%$; ether extract $4.2 \%$; ash $6.2 \%$; starch $1.8 \%$; DM $89.2 \%$ of as fed.

${ }^{3} 21.0 \% \mathrm{Ca} ; 15.6 \% \mathrm{P} ; 3.0 \% \mathrm{Mg} ; 3.9 \% \mathrm{~S} ; 150 \mathrm{mg} / \mathrm{kg}$ of Co; $2,000 \mathrm{mg} /$ $\mathrm{kg}$ of $\mathrm{Cu} ; 5,000 \mathrm{mg} / \mathrm{kg}$ of Mn; 11,903 mg/kg of Zn; $82 \mathrm{mg} / \mathrm{kg}$ of Se; $200 \mathrm{mg} / \mathrm{kg}$ of I; $1,000 \mathrm{kIU} / \mathrm{kg}$ of vitamin A; $220 \mathrm{kIU} / \mathrm{kg}$ of vitamin D; $6,200 \mathrm{IU} / \mathrm{kg}$ of vitamin $\mathrm{E}$.

${ }^{4} \mathrm{NFC}=100-(\mathrm{CP}+\mathrm{NDF}+$ ether extract + ash $)$.

${ }^{5}$ Penn State Particle Separator. Mean and SD of weekly samples.

the total intake of each ingredient divided by the total DMI of the treatment, assuming that orts had the same ingredient concentration as the offered TMR. The composition of the consumed TMR in nutrients and of the offered TMR in ingredients are in Table 1 . The particle size distribution of the fresh TMR was measured on weekly composites of daily samples with the Penn State Particle Separator using the 8- and 19-mm diameter screens and pan (Lammers et al., 1996).

Milk yield was recorded daily and samples were collected in proportion to the amount produced on each milking on $\mathrm{d} 6$ and 7 of each experimental week. Samples were obtained in flasks containing 2-bromo-2-nitropropano-1-3-diol and were stored under refrigeration for at most $2 \mathrm{~d}$ until shipping to a commercial laboratory. The concentrations in milk of protein, fat, lactose, TS, SCC, and MUN were measured by mid-infrared analysis (Bentley Instruments Inc., Chaska, MN) at the Laboratory of the Paraná State Holstein Breeders Association (APCBRH, Curitiba, Brazil). Milk energy secretion (Milk E; Mcal/d) was (NRC, 2001): [(0.0929 $\times \%$ fat $)+(0.0547 \times \%$ protein $)+(0.0395 \times \%$ lactose) $] \times \mathrm{kg}$ of milk. The secretion of ECM (kg/d) was Milk E/0.70 (assumes $0.70 \mathrm{Mcal} / \mathrm{kg}$ of milk with $3.7 \%$ fat, $3.2 \%$ protein, and $4.6 \%$ lactose). Calculated feed efficiencies were the ratios between milk yield and ECM to DMI. The BW was measured weekly after the morning milking. The gain in BW $(\mathrm{kg} / \mathrm{d})$ was calculated as the slope of the linear regression of weekly BW over time. The BCS (1 to 5) was measured at 14-d intervals by 3 independent evaluators (Wildman et al., 1982).

The total-tract apparent digestibility of DM, OM, $\mathrm{NDF}$, non-NDF OM, and starch were determined by total collection of feces during three 8-h periods from d 60 to 62 . Feces were collected concurrent to defecation and weighed. The second and third sampling periods were each delayed by $8 \mathrm{~h}$, thus representing a $24-\mathrm{h}$ collection. Fecal aliquots (equal fresh weight basis) were immediately frozen along the collection period and a composite sample was formed per cow. Concentrations of DM, NDF, ash, and starch were determined as previously described.

Total urinary output was collected in buckets, simultaneously to fecal sampling, to estimate the relative ruminal microbial yield based on allantoin excretion (mmol/d). A 20\% sulfuric acid solution $(200 \mathrm{~mL})$ was added to 20-L buckets and urine was added to it during the collection period. At the end of the 3 -d collection period, composite urine samples were diluted 1:5 with a $4 \%$ sulfuric acid solution and frozen at $-20^{\circ} \mathrm{C}$. Allantoin was analyzed according to Chen and Gomes (1992).

Ruminal fluid samples were collected on d 63 with a flexible oro-gastric tube connected to a vacuum pump. Samples were obtained $12.3 \pm 0.8 \mathrm{~h}$ after feeding. Cows were sampled in random order within each block. Samples were frozen in liquid nitrogen to suppress fermentation and stored at $-20^{\circ} \mathrm{C}$ until preparation for analysis of VFA. The molar proportions of acetate, propionate, and butyrate were determined by GLC (GC-17 ${ }^{\mathrm{a}}$, Shimadzu, Tokyo, Japan) equipped with an auto-injector (Shimadzu CBM-101) and a Nukol capillary fused silica column $(10 \mathrm{~m} \times 0.25 \mathrm{~mm} \times 0.25 \mathrm{~mm}$ film thickness, Supelco, Bellefonte, PA).

Blood samples for BUN (mg/dL) were collected from the coccygeal vessels on d 63 immediately before the first daily feeding and at $1,2,3,6,9,12$, and $18 \mathrm{~h}$ after feeding. The blood was collected in vacutainer tubes with EDTA, centrifuged at $1,000 \times g$ for 15 min at room temperature, and the plasma was frozen at $-20^{\circ} \mathrm{C}$ until analysis (Urea 500, Doles Reagentes para 
Laboratórios, Goiânia, Brazil). On the same day, blood samples were collected $12 \mathrm{~h}$ after feeding in tubes with potassium fluoride for glucose analysis (Glicose Enzimática Líquida, Doles Reagentes para Laboratórios).

Chewing activity and ingestion behavior were evaluated on d 59 by visual observation of the buccal activities of each cow at 5-min intervals continuously for $24 \mathrm{~h}$. Buccal activities evaluated were feed ingestion, water ingestion, rumination, and idleness. Ingestion and rumination per unit of DMI were calculated using the intake of the day in which chewing activity was evaluated. A meal was defined by at least 2 consecutive 5 -min ingestion events following at least $10 \mathrm{~min}$ of idleness or rumination. To generate the meal pattern data, the minimum 10-min inter-meal interval was adopted based on the reasoning of Mullins et al. (2012) for a 12-min interval. The duration of the first daily meal (conditioned meal) was measured with a chronometer. Five evaluators observed the behavior of all cows after offering feed at $0700 \mathrm{~h}$ until the last cow finished its first meal.

The proportions of daily intake in the morning (0700 to $1300 \mathrm{~h}$ ), afternoon (1300 to $1900 \mathrm{~h}$ ), and night (1900 to $0700 \mathrm{~h}$ ) were determined by measuring feed availability per cow at 0700, 1300, and $1900 \mathrm{~h}$ and orts at 1300, 1900, and 0700 h. Feed particles sorting behavior was evaluated according to Leonardi and Armentano (2003). The proportion of particles above the 19-mm mesh diameter screen and above and below the $8-\mathrm{mm}$ mesh screen of the Penn State Particle Separator (Lammers et al., 1996) was evaluated at 0700 and $1300 \mathrm{~h}$ for the offered TMR and at 1300, 1900, and $0700 \mathrm{~h}$ for refusals. Feed refusals at $1300 \mathrm{~h}$ were mixed with feed offered at $1300 \mathrm{~h}$ for measurement of the offered TMR particle size per cow. The predicted intake (as-fed basis) of particles on each screen was $\%$ TMR retained on screen $\times \mathrm{kg}$ of TMR consumed. The observed intake of particles was $\%$ TMR retained on screen $\times \mathrm{kg}$ of TMR offered $-\%$ orts retained on screen $\times \mathrm{kg}$ of orts. The selection index was $100 \times$ (observed intake/predicted intake). Sorting values below $100 \%$ represent selective refusal, above $100 \%$ represent preferential intake, and equal to $100 \%$ represent no selection.

\section{Statistical Analysis}

Data obtained over time were analyzed with the MIXED procedure of SAS (SAS Institute Inc., Cary, NC). The statistical model contained the continuous covariate effect (measurement of the same variable at the end of the standardization period), the random effect of block (1 to 14), the fixed effects of treatment (control, amylase) and time (d 1 to 63 or wk 1 to 9), and the interaction between treatment and time. Cow nested within treatment was defined as random. For each variable, the best covariance structure was defined by the Akaike's information criterion among first-order autoregressive, unstructured, and compound symmetry. Degrees of freedom were calculated using the KenwardRoger option. Similar models were used for variables measured once during the experiment and for variables without the covariate adjustment by removing the covariate, time, and its interaction with treatment from the previous model. Significance was declared at $P \leq$ 0.05 and trends at $0.05<P \leq 0.10$.

\section{RESULTS}

Data on intake and lactation performance are in Table 2. Amylase supplementation of the $32 \%$ starch diet (Table 1) increased milk yield $(+0.7 \mathrm{~kg} / \mathrm{d}, P=0.02)$ and reduced DMI $(-1.0 \mathrm{~kg} / \mathrm{d}, P<0.01)$, resulting in improved feed efficiency $(+0.12, P<0.01)$. Milk lactose yield was increased $(P=0.01)$, and a trend $(P=0.07)$ was observed for increased milk solids yield in response to amylase. Protein and fat yields and concentrations did not differ $(P \geq 0.35)$. The covariate adjusted BW and BCS did not differ $(P \geq 0.44)$, and neither did the daily BW gain $(P=0.67)$. Although no treatment effect was detectable on MUN ( $P=0.33)$, BUN was reduced $(P=0.05$, Figure 1$)$ by amylase. A trend $(P=0.07)$ for increased plasma glucose concentration was observed in response to amylase supplementation (Table 3).

The total-tract starch and NDF digestibility were not affected $(P \geq 0.41)$ by amylase supplementation (Table $3)$. In addition, no difference was observed in the molar proportions of acetate, propionate, and butyrate in ruminal VFA $(P \geq 0.74)$. Treatment did not affect the urinary allantoin excretion $(P=0.54)$, which suggests that microbial protein yield did not differ (Table 3 ).

Chewing and ingestion behaviors are in Table 4 . Cows fed amylase tended $(P=0.10)$ to have shorter ingestion time per day and had $(P=0.05)$ shorter chewing time per day than cows fed the control. The number of meals per day was also reduced $(P=0.03)$ by amylase, but the duration of the first daily meal was unaffected $(P=0.54)$. The proportion of intake in periods of the day did not differ $(P \geq 0.28)$. However, amylase induced $(P<0.01)$ selective sorting in favor of long feed particles $(>19 \mathrm{~mm})$ in the morning and at night and selective refusal of short feed particles $(<8$ $\mathrm{mm})$ at night. Amylase also induced $(P=0.02)$ lower degree of refusal of medium feed particles $(8-19 \mathrm{~mm})$ at night than the control. 


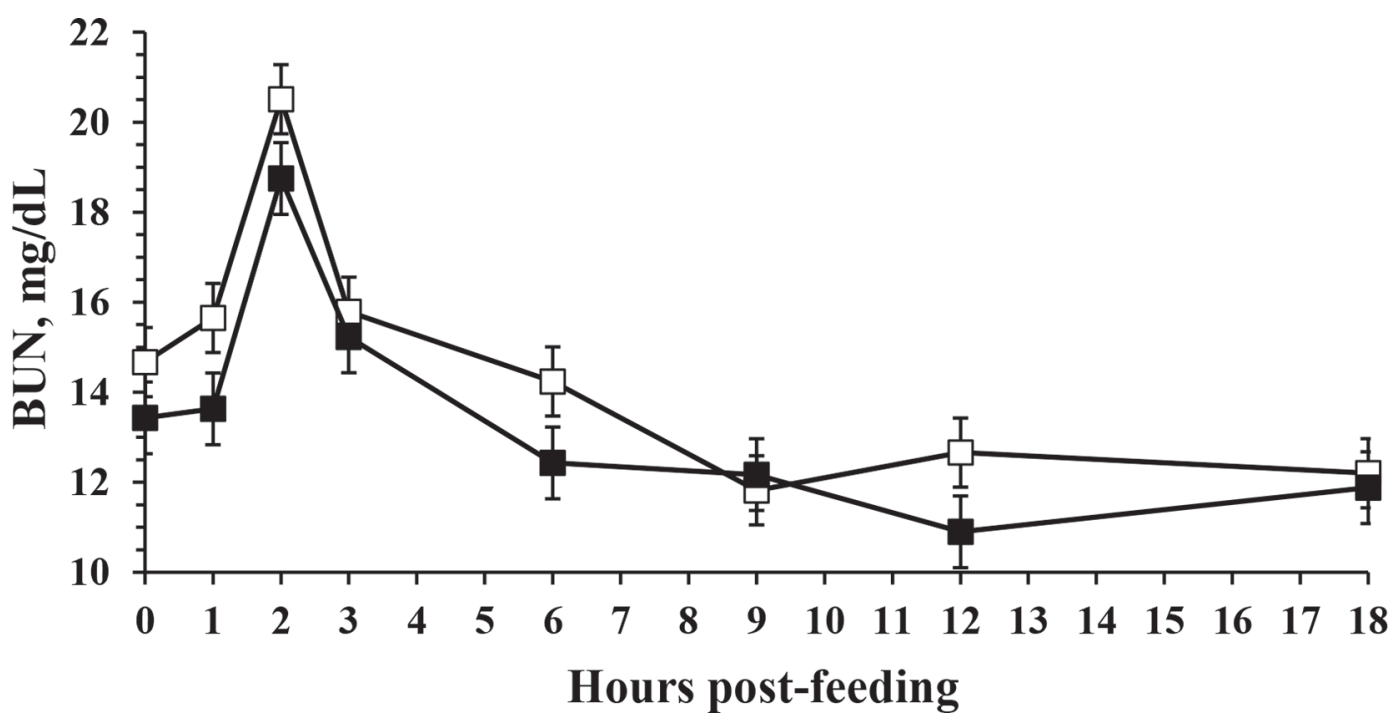

Figure 1. Blood urea $\mathrm{N}$ during the day on control $(\square)$ and amylase $(\boldsymbol{\square})$ treatments. Treatment means: control $=14.7 \mathrm{mg} / \mathrm{dL}$, amylase 13.6 $\mathrm{mg} / \mathrm{dL}$. SEM $=0.36$. $P$-values: 0.05 for treatment, $<0.01$ for time, and 0.26 for the interaction of treatment and time. Error bars represent SEM.

\section{DISCUSSION}

The supplementation of exogenous amylase to the high-starch diet increased feed efficiency, as the result of increased milk yield and reduced DMI. The reduction in DMI was supported by the reduction in ingestion and chewing behavior per day. Improved feed efficiency in response to the long-term supplementation of the same amylase product has been observed previously (Gencoglu et al., 2010; Ferraretto et al., 2011). However, the gain in feed efficiency has been driven by increased milk yield at the same DMI (Ferraretto et al., 2011) or by reduced DMI at the same milk yield (Gencoglu et al., 2010). The experiments of Gencoglu et al. (2010) and Ferraretto et al. (2011) used $21 \%$ starch diets instead of the $32 \%$ dietary starch concentration of our experiment. Dietary starch concentration may be involved in the difference in animal response to exogenous amylase. Nozière et al. (2014) observed no difference in shortterm DMI in response to exogenous amylase (18.9 $\mathrm{kg} / \mathrm{d}$ ), but the enzyme tended to increase milk yield when added to a $30 \%$ starch diet (24.7 vs. $25.3 \mathrm{~kg} / \mathrm{d}$ ) and had no effect on milk yield when dietary starch was $20 \%$ (24.0 vs. $23.7 \mathrm{~kg} / \mathrm{d}$ ). Weiss et al. (2011) observed

Table 2. Intake, lactation performance, MUN, BW, BCS, and feed efficiency on control and amylase treatments

\begin{tabular}{lcccrcc}
\hline & & & & \multicolumn{3}{c}{$P^{2}$-value $^{1}$} \\
\cline { 5 - 7 } Item & Control & Amylase & SEM & Treat & Time & Treat $\times$ Time \\
\hline DMI, kg/d & 20.7 & 19.7 & 0.16 & $<0.01$ & $<0.01$ & 0.88 \\
Milk, kg/d & 32.3 & 33.0 & 0.18 & 0.02 & $<0.01$ & 0.91 \\
ECM, kg/d & 31.0 & 31.5 & 0.24 & 0.16 & $<0.01$ & 0.96 \\
Fat, kg/d & 1.115 & 1.108 & 0.0110 & 0.66 & $<0.01$ & 0.97 \\
Protein, kg/d & 1.012 & 1.024 & 0.0089 & 0.35 & $<0.01$ & 0.94 \\
Lactose, kg/d & 1.494 & 1.539 & 0.0110 & 0.01 & $<0.01$ & 0.93 \\
Solids, kg/d & 3.913 & 3.996 & 0.0290 & 0.07 & $<0.01$ & 0.95 \\
Fat, \% & 3.49 & 3.38 & 0.083 & 0.41 & $<0.01$ & 0.43 \\
Protein, \% & 3.20 & 3.16 & 0.036 & 0.40 & $<0.01$ & 0.86 \\
Lactose, \% & 4.64 & 4.67 & 0.018 & 0.31 & $<0.01$ & 0.19 \\
Solids, \% & 12.26 & 12.19 & 0.076 & 0.59 & $<0.01$ & 0.19 \\
MUN, mg/dL & 15.7 & 16.0 & 0.33 & 0.53 & $<0.01$ & 0.50 \\
BW, kg & 647 & 645 & 11.4 & 0.90 & $<0.01$ & 0.17 \\
BW gain, kg/d & 0.199 & 0.142 & 0.0930 & 0.67 & & \\
BCS, 1 to 5 & 3.45 & 3.41 & 0.03 & 0.44 & $<0.01$ & 0.12 \\
Milk/DMI & 1.58 & 1.70 & 0.012 & $<0.01$ & $<0.01$ & 0.91 \\
ECM/DMI & 1.52 & 1.63 & 0.013 & $<0.01$ & $<0.01$ & 0.93 \\
\hline
\end{tabular}

${ }^{1}$ Treat $=$ treatment. Time $=\mathrm{d} 1$ to 63 or wk 1 to 9 . Treat $\times$ time $=$ interaction between treatment and time. 
Table 3. Total-tract apparent digestibility of nutrients, ruminal fermentation profile, urinary allantoin excretion, and plasma glucose concentration on control and amylase treatments

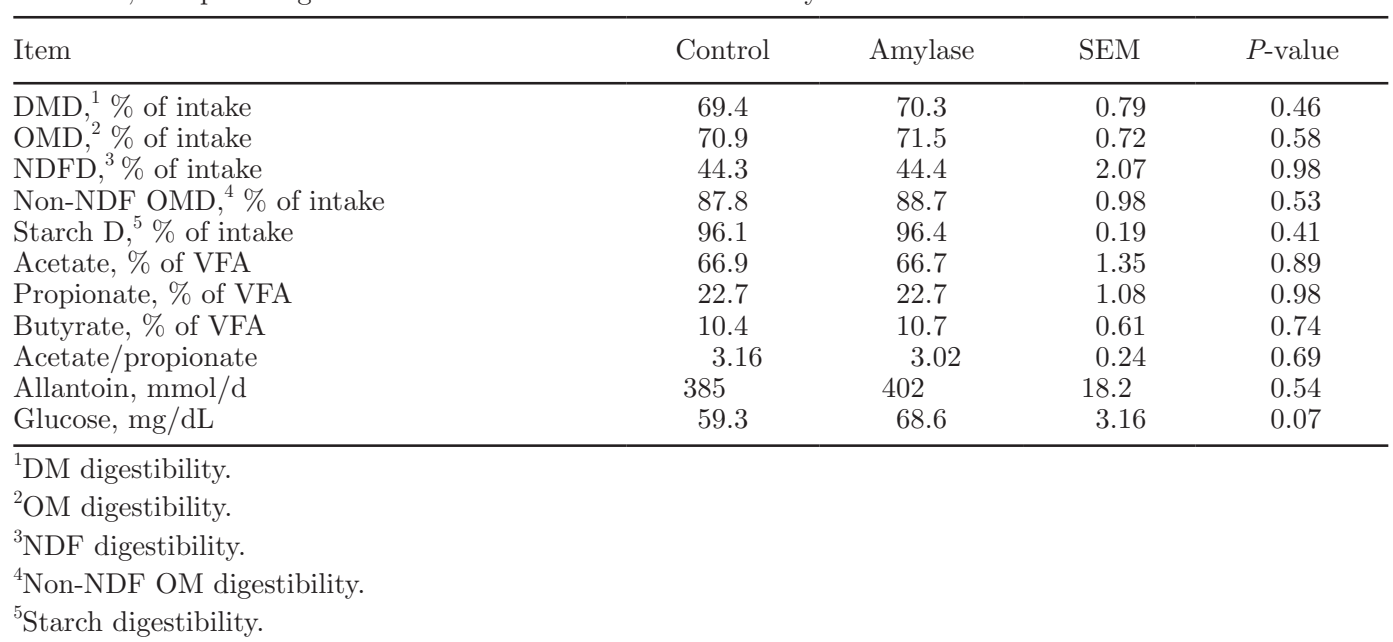

that amylase supplementation did not affect DMI, milk yield, or feed efficiency of lactating cows fed a $26 \%$ starch diet formulated with coarsely ground corn, supposedly of low ruminal digestibility $(87.8 \%$ total-tract starch digestibility). Improvement in feed efficiency is an expected response to exogenous amylase supplementation, although the animal response in DMI and milk yield seems to be variable and is apparently dependent on the concentration and type of starch in the diet or other uncontrolled cow and experimental factors.
Increased feed efficiency is a frequently observed animal response to corn starch processing by ensiling, steam-flaking, and rolling, usually associated with increased ruminal and total-tract starch digestibility (Ferraretto et al., 2013). Based on this meta-analysis (Ferraretto et al., 2013), expected animal responses to increased starch digestibility would be reduced DMI and milk fat \%, with no major effect on milk yield, protein \%, MUN, and ruminal and total-tract NDF digestibility. Amylase supplementation have not affected

Table 4. Chewing and ingestion behavior, proportion of daily intake in periods of the day, and particle size sorting behavior on control and amylase treatments

\begin{tabular}{lcccc}
\hline Item & Control & Amylase & SEM & $P$-value \\
\hline Ingestion, min/d & 347 & 291 & 22.4 & 0.10 \\
Rumination, min/d & 433 & 408 & 21.1 & 0.41 \\
Chewing, ${ }^{1}$ min/d & 780 & 699 & 26.3 & 0.05 \\
Ingestion, min/kg of DMI & 16.8 & 15.2 & 1.24 & 0.40 \\
Rumination, min/kg of DMI & 20.6 & 21.7 & 1.43 & 0.58 \\
Chewing, ${ }^{1}$ min/kg of DMI & 37.4 & 37.0 & 2.01 & 0.89 \\
Meals/d & 11.5 & 9.7 & 0.53 & 0.03 \\
First meal duration, min & 43.5 & 39.0 & 3.87 & 0.54 \\
0700 to $1300 \mathrm{~h}, \%$ of as-fed intake & 34.7 & 37.2 & 1.98 & 0.40 \\
1300 to $1900 \mathrm{~h}, \%$ of as-fed intake & 41.7 & 39.0 & 1.62 & 0.28 \\
1900 to 0700 h, \% of as-fed intake & 23.6 & 23.8 & 2.11 & 0.95 \\
Sorting 0700 to $1300 \mathrm{~h}$, observed/predicted, ${ }^{2} \%$ & 117 & 155 & 8.4 & $<0.01$ \\
$>19 \mathrm{~mm}$ & 110 & 97 & 8.1 & 0.28 \\
$8-19 \mathrm{~mm}$ & 96 & 94 & 2.4 & 0.57 \\
$<8 \mathrm{~mm}$ & & & & \\
Sorting 1300 to $1900 \mathrm{~h}$, observed/predicted, ${ }^{2} \%$ & 143 & 125 & 9.6 & 0.22 \\
$>19 \mathrm{~mm}$ & 107 & 107 & 4.4 & 0.98 \\
$8-19 \mathrm{~mm}$ & 92 & 96 & 2.1 & 0.22 \\
$<8 \mathrm{~mm}$ & & & & \\
Sorting 1900 to $0700 \mathrm{~h}$, observed/predicted, ${ }^{2} \%$ & 91 & 129 & 6.9 & $<0.01$ \\
$>19 \mathrm{~mm}$ & 85 & 97 & 3.4 & 0.02 \\
$8-19 \mathrm{~mm}$ & 104 & 97 & 1.3 & $<0.01$ \\
\hline $8 \mathrm{~mm}$ & & &
\end{tabular}

${ }^{1}$ Chewing $=$ ingestion + rumination.

${ }^{2}$ Penn State Particle Separator. $>100=$ preferential intake, $<100=$ refusal, $100=$ no sorting. 
milk fat, protein, and lactose concentrations and yields in other experiments (Gencoglu et al., 2010; Ferraretto et al., 2011; Weiss et al., 2011; Nozière et al., 2014), although Gencoglu et al. (2010) detected a trend for increased milk protein concentration in response to exogenous amylase. In our experiment, the increase in feed efficiency induced by amylase was associated wit increased milk lactose yield and no effect on the secretions of protein and fat.

The increase in lactose yield is plausibly associated with the increase in plasma glucose concentration (Santos et al., 2017). Lactose is an important product of mammary glucose uptake (Zhao, 2014). Glucose is also known to be potentially hypophagic in ruminants (Larsen and Kristensen, 2009; Larsen et al., 2010), although the role of glucose in regulation of DMI is controversial (Allen, 2000). Hurtaud et al. (1998) observed that the infusion of increasing amounts of glucose into the duodenum of lactating cows induced a linear decrease in DMI.

The increase in plasma glucose concentration in response to amylase could have been the result of increases in ruminal fermentation of starch and net absorption of propionate for gluconeogenesis in the liver (Reynolds et al., 1988). However, changes in ruminal VFA profile were not detected, suggesting that amylase supplementation did not induce major alteration in ruminal fermentation. Nozière et al. (2014) observed a reduction in the molar proportion of acetate and an increase in propionate when exogenous amylase supplemented a $30 \%$ starch diet, but the enzyme did not affect the ruminal VFA profile when a $20 \%$ starch diet was fed. These authors (Nozière et al., 2014), observed that exogenous amylase induced a greater absolute increase in ruminal starch digestibility of a high-starch diet $(+7.2$ percentage units) than of a low-starch diet $(+5.8$ percentage units), probably explaining the change in ruminal fermentation profile in response to amylase only when the high-starch diet was fed. Although a reduction in the acetate to propionate ratio was expected when amylase supplemented the high starch in our experiment, the change in ruminal fermentation profile may have not been of large enough magnitude to be detected experimentally. Amylase induced only a numerical reduction in the ruminal acetate to propionate ratio.

The reduction in BUN over time suggests that amylase increased the ruminal degradation of starch, although MUN was not responsive to the enzyme. Increased ruminal starch digestibility in response to exogenous amylase was not capable of affecting MUN, ruminal ammonia concentration, and the partition of $\mathrm{N}$ utilization in dairy cows (Nozière et al., 2014). Ferraretto et al. (2011) and Weiss et al. (2011) also did not detect changes in MUN in response to amylase, although Gencoglu et al. (2010) observed a reduction. Intensive sampling of BUN over time may be required to detect changes in ruminal $\mathrm{N}$ metabolism induced by the enzyme. Urinary allantoin excretion also did not respond to amylase, suggesting that ruminal microbial yield did not differ, consistent with the lack of an amylase effect on microbial $\mathrm{N}$ flow to the duodenum of lactating cows (Nozière et al., 2014).

Cows fed amylase selected in favor of long feed particles and rejected short feed particles, without a major effect of sorting behavior on the nutrient composition of the consumed diet. When ruminal acidosis was induced experimentally, cows had preferential consumption of long feed particles, which is a behavior thought to be an animal response to attenuate low ruminal $\mathrm{pH}$ (Keunen et al., 2002; DeVries et al., 2008; Maulfair et al., 2013; Kmicikewycz and Heinrichs, 2015). The selection in favor of long particles in our experiment suggests that ruminal starch degradation may have been increased by amylase. Greater fermentation of starch with amylase may have induced some acidosis, and cows sorted in favor of longer particles to compensate, attenuating any response in ruminal fermentation profile.

Total-tract starch digestibility was not affected by amylase. Starch digestibility was high (96.3\% of intake), which possibly precluded the detection of a positive effect of amylase on digestibility. However, the formulation of a $26 \%$ of starch diet with ruminally resistant starch was not associated with increased total-tract starch digestibility in response to amylase (Weiss et al., 2011). In vivo estimates of ruminal starch digestibility suggest that the proportion of starch digested in the rumen or intestine can have large variation in lactating cows. Ruminal starch digestibility ranged from a mean value of $44.6 \%$ of intake for diets based on dry corn cracked or rolled to $86.8 \%$ of intake for high-moisture corn diets in the meta-analysis of Firkins et al. (2001). However, the compensatory action of the intestines on starch digestibility reduces the difference in ruminal digestibility among diets (Oba and Allen, 2003b). Minor changes in total-tract starch digestibility may occur between diets with large difference in site of starch digestion in the digestive tract (Nozière et al., 2014; Fredin et al., 2015). The potential increase in ruminal starch degradation induced by amylase was not reflected in increased total-tract starch digestibility.

Exogenous amylase supplementation had no effect on the total-tract NDF digestibility, in disagreement with other experiments (Gencoglu et al., 2010; Weiss et al., 2011). The diets of Gencoglu et al. (2010) and Weiss et al. (2011) had soy hulls as a source of nonforage fiber. The nature of the fiber in the diet may be a factor on 
the response in NDF digestibility to amylase supplementation and may deserve further evaluation. Nozière et al. (2014) observed that exogenous amylase had no effect on ruminal and total-tract NDF digestibility. Amylase reduced the concentration of the fibrolytic bacteria Fibrobacter succinogenes and had no effect on Streptococcus bovis in ruminal fluid, although changes in bacterial community were minor (Nozière et al., 2014). The positive effect of amylase supplementation on NDF digestibility did not occur in our experiment.

\section{CONCLUSIONS}

Amylase increased milk yield and reduced DMI, improving feed efficiency of dairy cows, associated with an increase in plasma glucose concentration and milk lactose synthesis. Amylase induced selective sorting in favor of long feed particles and reduced the concentration of urea- $\mathrm{N}$ in blood. The total-tract apparent digestibility of nutrients was not increased by amylase.

\section{ACKNOWLEDGMENTS}

The authors are grateful to Fapemig (Minas Gerais Foundation for Research Support, Belo Horizonte, Brazil) and $\mathrm{CNPq}$ (National Research Council, Brasilia, Brazil) for the grants to the authors, to DSM Produtos Nutricionais Brasil S.A. (São Paulo, Brazil) for partially funding the project, and to the members of Grupo do Leite of the University of Lavras (Lavras, Brazil) for the help in data collection and animal care.

\section{REFERENCES}

Allen, M. S. 2000. Effects of diet on short-term regulation of feed intake by lactating dairy cattle. J. Dairy Sci. 83:1598-1624.

Allen, M. S., B. J. Bradford, and M. Oba. 2009. The hepatic oxidation theory of the control of feed intake and its application to ruminants. J. Anim. Sci. 87:3317-3334.

Andrade Filho, R., R. B. Reis, M. N. Pereira, and R. C. Souza. 2010 Reconstitution and ensiling of dry mature corn grains. Page 10 in Proc. 47a Reunião Anual da Sociedade Brasileira de Zootecnia, Salvador, Brazil.

AOAC International. 2012. Official Methods of Analysis. 19th ed. AOAC Int., Arlington, VA.

Chen, X. B., and M. J. Gomes. 1992. Estimation of microbial protein supply to sheep and cattle based on urinary excretion of purine derivatives: An overview of technical details. Int. Feed Res. Unit, Occasional Publ. Rowett Research Institute, Aberdeen, United Kingdom.

Cotta, M. A. 1988. Amylolytic activity of selected species of ruminal bacteria. Appl. Environ. Microbiol. 54:772-776.

DeVries, T. J., F. Dohme, and K. A. Beauchemin. 2008. Repeated ruminal acidosis challenges in lactating dairy cows at high and low risk for developing acidosis: Feed sorting. J. Dairy Sci. 91:3958 3967.

Ferraretto, L. F., P. M. Crump, and R. D. Shaver. 2013. Effect of cereal grain type and corn grain harvesting and processing methods on intake, digestion, and milk production by dairy cows through a meta-analysis. J. Dairy Sci. 96:533-550.

Ferraretto, L. F., S. M. Fredin, and R. D. Shaver. 2015. Influence of ensiling, exogenous protease addition and bacterial inoculation on fermentation profile, nitrogen fractions and ruminal in vitro starch digestibility in rehydrated and high-moisture corn. J. Dairy Sci. 98:7318-7327.

Ferraretto, L. F., R. D. Shaver, M. Espineira, H. Gencoglu, and S. J. Bertics. 2011. Influence of a reduced-starch diet with or without amylase on lactation performance by dairy cows. J. Dairy Sci. 94:1490-1499.

Firkins, J. L., M. L. Eastridge, N. R. St-Pierre, and S. M. Noftsger. 2001. Effects of grain variability and processing on starch utilization by lactating dairy cattle. J. Anim. Sci. 79:E218-E238.

Fredin, S. M., L. F. Ferraretto, M. S. Akins, S. J. Bertics, and R. D. Shaver. 2015. Effects of corn-based diet starch content and corn particle size on lactation performance, digestibility, and bacterial protein flow in dairy cows. J. Dairy Sci. 98:541-553.

Gencoglu, H., R. D. Shaver, W. Steinberg, J. Ensink, L. F. Ferraretto, S. J. Bertics, and M. S. Akins. 2010. Effect of feeding a reducedstarch diet with or without amylase addition on lactation performance in dairy cows. J. Dairy Sci. 93:723-732.

Hall, M. B. 2009. Analysis of starch, including maltooligosaccharides, in animal feeds: A comparison of methods and a recommended method for AOAC collaborative study. J. AOAC Int. 92:42-49.

Hall, M. B., and C. Herejk. 2001. Differences in yields of microbial crude protein from in vitro fermentation of carbohydrates. J. Dairy Sci. 84:2486-2493.

Hurtaud, C., H. Rulquin, and R. Vérité. 1998. Effects of graded duodenal infusions of glucose on yield and composition of milk from dairy cows. 1. Diets based on corn silage. J. Dairy Sci. 81:3239-3247.

Jung, S., and K. Vogel. 2008. Determination of Ronozyme RumiStar Alpha-Amylase Activity in Feed and Per Se Samples. DSM Nutritional Products Ltd. Regulatory Report No. 2500706. DSM Nutritional Products Ltd., Basel, Switzerland.

Keunen, J. E., J. C. Plaizier, L. Kyriazakis, T. F. Duffield, T. M. Widowski, M. I. Lindinger, and B. W. McBride. 2002. Effects of a subacute ruminal acidosis model on the diet selection of dairy cows. J. Dairy Sci. 85:3304-3313.

Klingerman, C. M., W. Hu, E. E. McDonell, M. C. DerBedrosian, and L. Kung. 2009. An evaluation of exogenous enzymes with amylolytic activity for dairy cows. J. Dairy Sci. 92:1050-1059.

Kmicikewycz, A. D., and A. J. Heinrichs. 2015. Effect of corn silage particle size and supplemental hay on rumen $\mathrm{pH}$ and feed preference by dairy cows fed high-starch diets. J. Dairy Sci. 98:373-385.

Lammers, B. P., D. R. Buckmaster, and A. J. Heinrichs. 1996. A simple method for the analysis of particle sizes of forage and total mixed rations. J. Dairy Sci. 79:922-928.

Larsen, M., and N. B. Kristensen. 2009. Effect of abomasal glucose infusion on splanchnic and whole-body glucose metabolism in periparturient dairy cows. J. Dairy Sci. 92:1071-1083.

Larsen, M., A. E. Relling, C. K. Reynolds, and N. B. Kristensen. 2010. Effect of abomasal glucose infusion on plasma concentrations of gut peptides in periparturient dairy cows. J. Dairy Sci. 93:5729-5736

Leonardi, C., and L. E. Armentano. 2003. Effect of quantity, quality, and length of alfalfa hay on selective consumption by dairy cows. J. Dairy Sci. 86:557-564.

Maulfair, D. D., K. K. McIntyre, and A. J. Heinrichs. 2013. Subacute ruminal acidosis and total mixed ration preference in lactating dairy cows. J. Dairy Sci. 96:6610-6620.

Mullins, C. R., L. K. Mamedova, M. J. Brouk, C. E. Moore, H. B. Green, K. L. Perfield, J. F. Smith, J. P. Harner, and B. J. Bradford. 2012. Effects of monensin on metabolic parameters, feeding behavior, and productivity of transition dairy cows. J. Dairy Sci. 95:1323-1336

Nozière, P., W. Steinberg, M. Silberberg, and D. P. Morgavi. 2014 Amylase addition increases starch ruminal digestion in first-lactation cows fed high and low starch diets. J. Dairy Sci. 97:2319-2328. 
NRC. 2001. Nutrient Requirements of Dairy Cattle. 7th rev. ed. Natl. Acad. Sci., Washington, DC.

Oba, M., and M. S. Allen. 2003a. Effects of corn grain conservation method on feeding behavior and productivity of lactating dairy cows at two dietary starch concentrations. J. Dairy Sci. 86:174183.

Oba, M., and M. S. Allen. 2003b. Effects of corn grain conservation method on ruminal digestion kinetics for lactating dairy cows at two dietary starch concentrations. J. Dairy Sci. 86:184-194.

Reynolds, C. K., G. B. Huntington, and H. F. Tyrrell. 1988. Net metabolism of volatile fatty acid, D- $\beta$-hydroxybutyrate, nonesterified fatty acids, and blood gasses by portal-drained viscera and liver of lactating Holstein cows. J. Dairy Sci. 71:2395-2405.

Santos, W. P., C. L. S. Ávila, M. N. Pereira, R. F. Schwan, N. M. Lopes, and J. C. Pinto. 2017. Effect of the inoculation of sugarcane silage with Lactobacillus hilgardii and Lactobacillus buchneri on feeding behavior and milk yield of dairy cows. J. Anim. Sci. 95:4613-4622.
Tricarico, J. M., J. D. Johnston, and K. A. Dawson. 2008. Dietary supplementation of ruminant diets with an Aspergillus oryzae a-amylase. Anim. Feed Sci. Technol. 145:136-150.

Van Soest, P. J., J. B. Robertson, and B. A. Lewis. 1991. Methods for dietary fiber, neutral detergent fiber, and non-starch polysaccharides in relation to animal nutrition. J. Dairy Sci. 74:3583-3597.

Weiss, W. P., W. Steinberg, and M. A. Engstrom. 2011. Milk production and nutrient digestibility by dairy cows when fed exogenous amylase with coarsely ground dry corn. J. Dairy Sci. 94:2492-2499.

Wildman, E. E., G. M. Jones, P. E. Wagner, R. L. Boman, H. F. Troutt, and T. N. Lesch. 1982. A dairy-cow body condition scoring system and its relationship to selected production characteristics. J. Dairy Sci. 65:495-501.

Zhao, F. Q. 2014. Biology of glucose transport in the mammary gland. J. Mammary Gland Biol. Neoplasia 19:3-17. 